\section{Evaluation of Rootstock Resistance to Fusarium Wilt and Gummy Stem Blight and Effect on Yield and Quality of a Grafted 'Inodorus' Melon}

\author{
Paola Crinò ${ }^{1}$ \\ ENEA-Ente per le Nuove Tecnologie, 'Energia e l'Ambiente, Dipartimento \\ Biotecnologie, Agroindustria e Protezione della Salute, Via Anguillarese \\ 301, 00123 Rome, Italy

\section{Chiara Lo Bianco, Youssef Rouphael, Giuseppe Colla, and} \\ Francesco Saccardo \\ Università degli Studi della Tuscia, Dipartimento GEMINI, Via S. Camillo de \\ Lellis snc, 01100 Viterbo, Italy

\section{Antonino Paratore \\ Università degli Studi di Catania, Dipartimento OrtoFloroArboricoltura e Tecnologie Agroalimentari, Via Valdisavoia 5, 95123 Catania, Italy}

Additional index words. Cucumis melo L., Didymella bryoniae, Fusarium oxysporum f. sp. melonis, susceptible scion

\begin{abstract}
Grafting represents an effective tool for controlling the race 1,2 of Fusarium oxysporum f. sp. melonis (FOM) and Didymella bryoniae in melon (Cucumis melo L.). Although not considered a soilborne pathogen, $D$. bryoniae survives on plant remains in the soil. The lack of effective resistant commercial hybrids and the gradual reduced use of soil fumigation with methyl bromide increase the risk of damages by both these pathogens. We determined the effectiveness of eight commercial rootstocks, ' $R S$ 841', 'P 360', 'ES 99-13', 'Elsi' (Cucurbita maxima Duchesne $\times$ Cucurbita moschata Duchesne), and 'Belimo', 'Energia', 'Griffin', 'ES liscio' (Cucumis melo genotypes), for their resistance to FOM and D. bryoniae. During 2003 and 2004 growing seasons, the inodorus $F_{1}$ hybrid Incas was grafted onto each of these commercial rootstocks and then evaluated, under greenhouse conditions, in terms of productivity and fruit quality. Cucurbita rootstocks ('RS 841', 'P 360', 'ES 99-13', 'Elsi') were highly resistant both to the race 1,2 of $F O M(100 \%$ survival) and to $D$. bryoniae (almost absent crown lesions and low leaf disease index); this reaction clearly differed from that of both the $C$. melo rootstocks ('Belimo', 'Energia', 'Griffin', 'ES liscio') and the control Incas. In both years, the highest yield was recorded in the graft combination Incas/' $R S$ 841' with 5.6 and 8.1 $\mathrm{kg} \cdot \mathrm{m}^{-2}$ during 2003 and 2004, respectively. The Cucurbita rootstock ' $R S$ 841' produced yields higher than $C$. melo rootstocks ('Belimo', 'Energia', 'Griffin', 'ES liscio') and the control Incas. Fruit dry matter, titratable acidity, total soluble solid contents, fruit firmness, and Hunter color [ $L^{*}$ (brightness), $a^{*}$ (redness), and $b^{*}$ (yellowness) parameters] of grafted melons were similar to those of the plants grown on their own roots.
\end{abstract}

Melon (Cucumis melo L.) is one of the most economically important and widely cultivated vegetable crops in the Mediterranean region. In Italy, 26,615 ha are annually cultivated (ISTAT, 2005) with 23,157 ha

\footnotetext{
Received for publication 15 Nov. 2006. Accepted for publication 8 Feb. 2007.

We thank Dr. Salvatore Vona at the Cooperativa Agricola Aurora for skillfully managing the crops at the Santa Croce Camerina Farm, Ragusa, and at the Pachino Farm, Siracusa, South Italy. We also thank Dr. Carlo Scollo from ECOFABER Nursery of Modica (Ragusa, Italy) for providing the grafting materials. We thank Dr. Sergio Argento, Dr. Fabio Chiarello, and Dr. Antonio Li Rosi from the University of Catania (Italy) for laboratory analyses. We also thank Prof. Daniel Leskovar for critically reading the manuscript and his constructive comments.

${ }^{1}$ To whom reprint requests should be addressed; e-mail paola.crino@casaccia.enea.it
}

$(87 \%)$ in open-field and 3458 ha $(13 \%)$ under protected cultivation (greenhouses, plastic houses, and tunnels). In the last 30 years, melon cultivation in the greenhouse has become increasingly dependent on methyl bromide (MB) fumigation. This is attributable to the continuous cropping and, consequently, to the increasing soil contamination by pests and pathogens as Fusarium oxysporum $\mathrm{f}$. sp. melonis (FOM) and Didymella bryoniae (causal agent of gummy stem blight). Although not a soilborne pathogen, this last fungus causes crown rot at or near the soil level, and inoculum potential represented by plant-infected remains can represent a serious danger for the future cultivations of Cucurbitaceae (Davì et al., 1988).

However, MB has a number of disadvantages: 1) it is considered toxic to humans and animals during its application and dissipation periods (Ristaino and Thomas, 1997); 2) it is detected in groundwater (Wheeler and Kawar, 1997); 3) it is dissipated in the air, thus reducing the ozone layer (Montzaka et al., 1996) and increases skin cancer in humans (Diffey, 2004). For these reasons, 168 countries, including Italy, have agreed to gradually reduce the use of $\mathrm{MB}$. Alternatives to $\mathrm{MB}$ for soil fumigation are represented by use of other chemicals (e.g., metham sodium, formalin, chloropicrin, and so on), crop rotation, solarization, and use of resistant cultivars. Crop rotation appears to be ineffective because the chlamydospores of $F O M$ are able to survive for many years in the soil (Armstrong and Armstrong, 1978). Solarization has been used with good results against soilborne diseases of melon (Katan et al., 1976; Tjamos and Makrinakis, 1990), but it is not widespread because when the temperature is high enough for the application of this method, melon cultivation in the greenhouse is already in progress Disease-resistant cultivars were developed to limit damages incited by soilborne fungi (McCreight et al., 1993). However, no commercial hybrids completely resistant to the race 1,2 of FOM and to D. bryoniae are available; in both cases, only sources of partially effective quantitative resistances have been until now reported (Frantz and Jahn, 2004; Perchepied and Pitrat, 2004; Perchepied et al., 2005). High levels of resistance have been found in different genotypes of Cucurbitaceae spp. (Lhotsky et al., 1991; Trionfetti Nisini et al., 1999, 2000), but they are incompatible with the cultivated melon.

Grafting plants onto resistant rootstocks is a quick method that may enable the susceptible scion to control soilborne diseases and increase yield (Lee, 1994; Lee and Oda, 2003; Oda, 1995). Melon is a vegetable species in which grafting is performed intensively to control soilborne diseases (Bletsos, 2005; Cohen et al., 2002, 2005; Edelstein et al., 1999; Lee, 1994; Trionfetti Nisini et al., 2002) and improve yield and tolerance to environmental stresses (Colla et al., 2006; Rivero et al., 2003). Generally, melons are grafted onto the same species $(C$. melo $\mathrm{L}$.) and very rarely onto pumpkin (Cucurbita spp., Cucurbita moschata $\times$ Cucurbita maxima hybrids) and white gourd (Benincasa hispida) rootstocks. However, in these cases, the taste and the fruit shape may be often negatively affected by grafting, indicating that metabolites associated with fruit quality are translocated to the scion through the xylem. This decrease in fruit quality does not represent a general phenomenon but depends on the specific scion-rootstock interaction and on the particular combination of growing conditions, including the response to diseases (Cohen et al., 2002).

This work aims 1) at verifying the level of resistance to the race 1,2 of FOM and D. bryoniae of commercial Cucurbita and Cucumis rootstocks and 2) at determining the influence of the rootstocks on yield and fruit quality when used in graft combinations with the melon hybrid Incas under greenhouse conditions. 


\section{Materials and Methods}

Characteristics of rootstocks used. Name, definition, and source of rootstocks are given in Table 1. These rootstocks were chosen for their good level of resistance to the race 1,2 F. oxysporum f. sp. melonis (Trionfetti Nisini et al., 2002) and to D. bryoniae (Trionfetti Nisini et al., 2000). The $F_{1}$ hybrid Incas (Clause Tézier, Italia Spa, Venaria Reale, Torino, Italy) was used as control in the inoculation tests with both FOM and D. bryoniae. 'Incas' belongs to the inodorus group of $C$. melo and is known as winter melon. This is a latematuring melon characterized by a firm and sweet flesh, usually white or green, a cucumber-like aroma, and a long shelf life. Traditionally, 'Incas' is grown for local consumption or long-distance transport during the fall-winter period. In our work, it was chosen for its tolerance to powdery mildew, which is a disease seriously threatening several Italian greenhouse cultivations of melon.

Inoculation tests. For the race 1,2 of $F O M$, artificial inoculations were performed under controlled conditions $\left(24 \pm 1{ }^{\circ} \mathrm{C} ; 16 \mathrm{~h}\right.$ light $/ 8 \mathrm{~h}$ dark) on 15 plantlets per genotype at the first-true-leaf stage. Plants were arranged in a completely randomized design with nine treatments (eight commercial rootstocks and one scion) and three replications of 15 plants for each treatment. The inoculum was represented by the fungal suspension containing $10^{6}$ conidia $/ \mathrm{mL}^{-1}$ collected from 20 -day old potato dextrose agar cultures of an Italian highly aggressive isolate (ISPaVe No. 1018, VCG 0134 ) of the race $1,2 \mathrm{w}$. Inoculations were performed during transplantation of plantlets into sterile soil. Roots were washed with tap water, pruned to $\approx 1.0$ to $1.5 \mathrm{~cm}$, and then dipped for $10 \mathrm{~min}$ into $5 \mathrm{~mL}$ of the fungal suspension. To facilitate inoculum absorption into the plant, the seedling trays were kept at $24 \pm 1{ }^{\circ} \mathrm{C}$ and watered, for the first time, only the day after inoculation. The percentages of healthy, symptomatic (progressive wilting on leaves) and dead plants per genotype were recorded $40 \mathrm{~d}$ after inoculation.

The isolate CP 1799 of D. bryoniae, supplied by the Royal Veterinary and Agricultural University of Copenhagen, Denmark, was cultured for $14 \mathrm{~d}$ at $24 \pm 1{ }^{\circ} \mathrm{C}$ and $12 \mathrm{~h}$ light on malt agar (Oxoid, Basingstoke, UK) to induce sporulation (Keinath et al., 1995). Six of the commercial rootstocks tested for resistance to the race 1,2 of FOM ('RS 841', 'P360', 'ES 99-13', 'Elsi', Belimo', 'Energia') and 'Incas' were also tested for resistance to D. bryoniae. Plants were arranged in a completely randomized design with seven treatments (six commercial rootstocks and one scion) and three replications of 15 plants for each treatment. Plantlets with three or four fully expanded true leaves, grown in the greenhouse at $24 \pm 2$ ${ }^{\circ} \mathrm{C}$, were sprayed with a fungal suspension containing $5 \times 10^{5}$ spores $/ \mathrm{mL}^{-1}$ of the pathogen according to the procedure described by Trionfetti Nisini et al. (2000). Damage severity both on leaf and stem was scored $21 \mathrm{~d}$ after inoculation using the 1 to 5 scale (for leaves: 1
$=0 \%$ of leaf area affected, $5=75 \%$ to $100 \%$; for stems: $1=$ no damage, $5=$ seedling dead) described by Zhang et al. (1997).

Greenhouse conditions. Two experiments were conducted, one in 2003 (Expt. 1) and one in 2004 (Expt. 2) in a $250-\mathrm{m}^{2}$ unheated polyethylene greenhouse situated on the Santa Croce Camerina Farm, Ragusa, South Italy (Expt. 1) and on the Pachino Farm,
Siracusa, South Italy. Plants were grown under natural light conditions. The maximum and minimum air temperatures inside the greenhouse, during the experimental period, was recorded on a data log and saved on a personal computer. Seeds of the hybrid Incas were sowed 4 d later (26 Mar. 2003 and 3 Apr. 2004) and $7 \mathrm{~d}$ earlier (22 Mar. 2003 and 31 Mar. 2004) than the C. melo and the

Table 1. Name, definition, and source of melon rootstocks.

\begin{tabular}{|c|c|c|}
\hline Rootstocks & Definition & Source \\
\hline$\overline{\mathrm{RS}} 841$ & Cucurbita maxima $\times$ Cucurbita moschata & $\begin{array}{l}\text { Royal Sluis Spa, Mirandola } \\
\text { (Modena), Italy }\end{array}$ \\
\hline P 360 & Cucurbita maxima $\times$ Cucurbita moschata & $\begin{array}{l}\text { SAIS Sementi S.p.A., Cesena } \\
\text { (Forli e Cesena), Italy }\end{array}$ \\
\hline ES 99-13 & Cucurbita maxima $\times$ Cucurbita moschata & Esasem Spa, Casaleone (Verona), Italy \\
\hline Elsi & Cucurbita maxima $\times$ Cucurbita moschata & Vilmorin Italia srl, Funo (Bologna), Italy \\
\hline Belimo & Cucumis melo & $\begin{array}{l}\text { Nunhems Sementi srl, S. Agata Bolognese } \\
\text { (Bologna), Italy }\end{array}$ \\
\hline Energia & Cucumis melo & $\begin{array}{l}\text { SEMINIS Vegetable Seeds Italia Srl, } \\
\text { Parma, Italy }\end{array}$ \\
\hline Griffin & Cucumis melo & PEOTEC Seeds srl, Sissa (Parma), Italy \\
\hline ES liscio & Cucumis melo & Esasem Spa, Casaleone (Verona), Italy \\
\hline
\end{tabular}
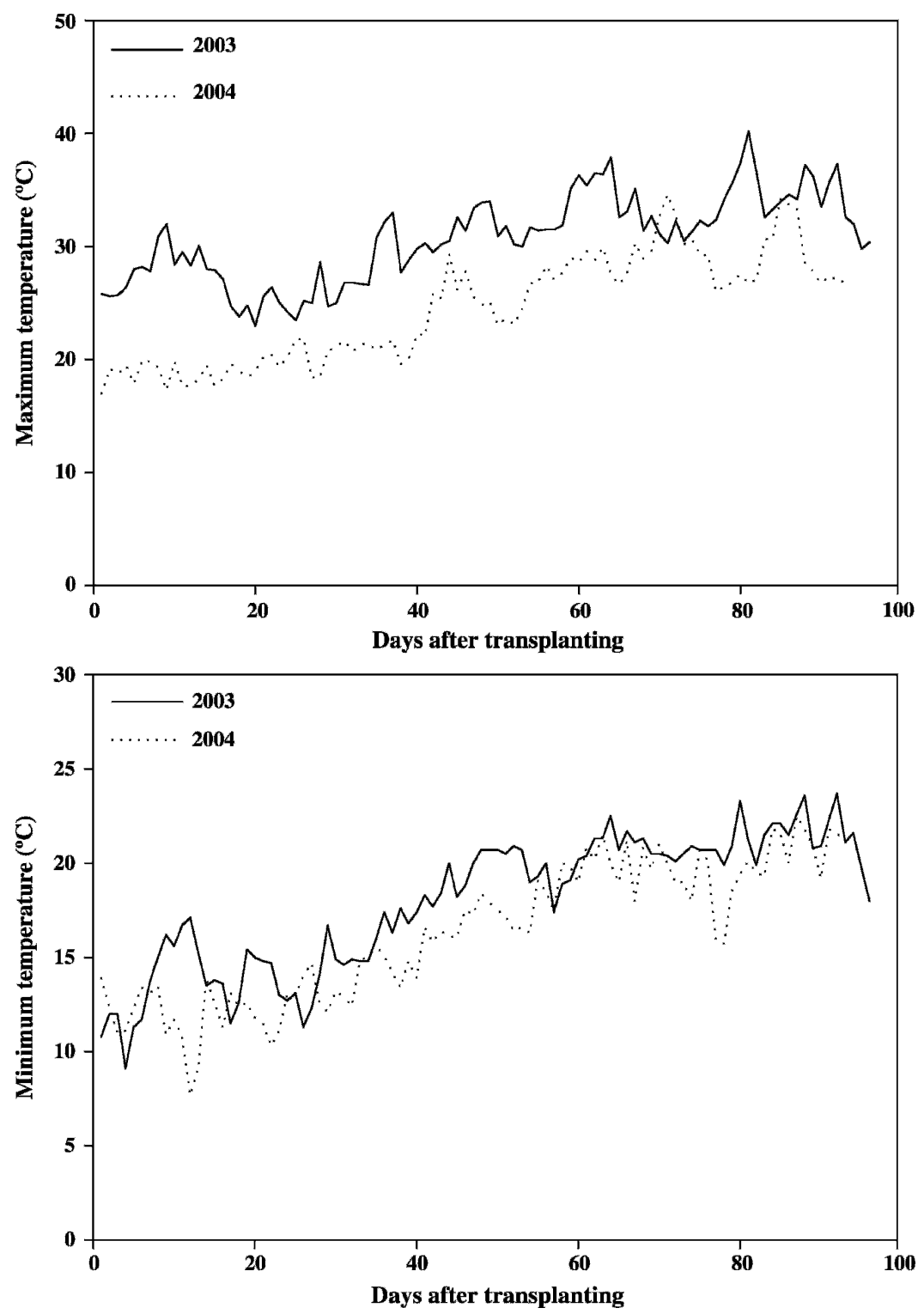

Fig. 1. Daily maximum and minimum air temperatures $\left({ }^{\circ} \mathrm{C}\right)$ recorded inside the greenhouse during Expt. 1 (29 Apr. to 2 Aug. 1003) and Expt. 2 (29 Apr. to 30 July 2004). 
Cucurbita rootstocks seeds, respectively. The tongue approach was used for grafting the scion Incas onto the commercial rootstocks (Table 1) according to the procedure described by Lee (1994). In both experiments, a randomized complete block design with three replications was used. Each experimental unit consisted of six plants. Grafted and ungrafted melon plants were transplanted on 29 Apr. 2003 (Expt. 1) and on 29 Apr. 2004 (Expt. 2). The soil was a sandy loam with a $\mathrm{pH}$ of 8.2. Plants were grown in single rows $(2 \mathrm{~m} \times 0.96 \mathrm{~m})$ at a plant density of 0.52 plants $/ \mathrm{m}^{2}$. Drip irrigation tape was installed on the soil surface at $20-\mathrm{cm}$ distance from the plant row. The irrigation tape (T-tape; T-systems International, San Diego) had outlets for watering at $30-\mathrm{cm}$ intervals and with a flow rate of $4 \mathrm{~L} \cdot \mathrm{h}^{-1}$ per emitter.

In both experiments, preplant broadcast $\mathrm{N}-\mathrm{P}-\mathrm{K}$ fertilizer $(12 \mathrm{~N}-15 \mathrm{P}-18 \mathrm{~K})$ was applied at a dose of $400 \mathrm{~kg} \cdot \mathrm{ha}^{-1}$ to all plots. Additional $\mathrm{N}$ at $100 \mathrm{~kg} \cdot \mathrm{ha}^{-1}, \mathrm{~K}$ at $130 \mathrm{~kg} \cdot \mathrm{ha}^{-1}$, and $\mathrm{Ca}$ at $66 \mathrm{~kg} \cdot \mathrm{ha}^{-1}$ were applied as potassium nitrate $(13 \mathrm{~N}, 44 \mathrm{~K})$, calcium nitrate $(15.5 \mathrm{~N}, 19 \mathrm{Ca})$, and ammonium nitrate $(34 \mathrm{~N})$ through the drip irrigation system in four equal proportions at 10 -d intervals starting 2 weeks after transplanting. Plants were kept free from weeds, insects, and diseases using greenhouse standard management procedures. The experiments were concluded on 2 Aug. 2003 (96 d after transplanting, Expt. 1) and on 30 July 2004 (93 d after transplanting, Expt. 2).

Measurements and analysis. Nine mature fruits per treatment (three fruits per replication) were harvested on 2 Aug. 2003 (Expt. 1) and on 30 July 2004 (Expt. 2). The numbers of fruits $\left(\mathrm{no} . / \mathrm{m}^{2}\right)$, the mean fruit weights $(\mathrm{kg})$, and the total yield $\left(\mathrm{kg} \cdot \mathrm{m}^{-2}\right)$ were determined on six plants per plot. Immediately after harvest, Hunter color values [parameters L* (brightness), a* (redness), and $\mathrm{b}^{*}$ (yellowness)] were measured on the surface of the external pulp with a Minolta colorimeter Model CR-300 (Minolta, Osaka, Japan). Pulp fruit firmness $\left(\mathrm{N} / \mathrm{cm}^{2}\right)$ was determined by a penetrometer (Texture Analyzer, Milano, Italy) fitted with a 4-mm diameter roundhead probe on three discs of the skin surface from the fruit equatorial area. From the liquid extract obtained by liquefying in a blender (Moulinex, Milano, Italy) and then filtering all mesocarp of each fruit, total soluble solids (TSS) content in juice was determined by an Atago N1 refractometer (Atago Co. Ltd., Tokyo) and expressed as ${ }^{\circ}$ Brix at $20{ }^{\circ} \mathrm{C}$. Acidity was determined by potentiometric titration with $0.1 \mathrm{M} \mathrm{NaOH}$ up to $\mathrm{pH} 8.1$ using $15 \mathrm{~mL}$ of juice. Results were expressed as percentage of citric acid in the juice. In both years, the fruits were dried in a forced-air oven at $80{ }^{\circ} \mathrm{C}$ for $72 \mathrm{~h}$ and weighed to determine the fruit dry matter (DM).

Statistical analysis. All data were statistically analyzed by analysis of variance using the SPSS software package (SPSS 10 for Windows, 2001). Duncan's multiple range test was performed at $P=0.05$ on each of the variables measured.

\section{Results}

Climatic data. Differences between the two growing seasons in maximum $\left(\mathrm{T}_{\max }\right)$ and minimum $\left(\mathrm{T}_{\min }\right)$ air temperatures were observed (Fig. 1). During the 2003 growing season, the daily $\mathrm{T}_{\max }$ and $\mathrm{T}_{\min }$ ranged from 23.0 to $40.2{ }^{\circ} \mathrm{C}$ and from 9.1 to $23.7{ }^{\circ} \mathrm{C}$, respectively, whereas for the 2004 growing season, the daily $T_{\max }$ and $T_{\min }$ varied from 17.0 to $34.6{ }^{\circ} \mathrm{C}$ and from 7.7 to $23.9{ }^{\circ} \mathrm{C}$, respectively. Furthermore, the average daily $\mathrm{T}_{\max }$ of the first $30 \mathrm{~d}$ after transplanting, in the 2003 growing season, was higher than in the 2004 growing season $\left(27.6^{\circ} \mathrm{C}\right.$ versus $\left.19.0^{\circ} \mathrm{C}\right)$.

Fusarium and Didymella resistance. Mean values of inoculations tests with the race 1,2w of FOM indicated that the commercial Cucurbita rootstocks ('RS 841', 'P 360', 'ES 99-13', 'Elsi') had 100\% plant survival, which clearly differed from that of both the C. melo rootstocks (average 38\%) and the control (Fig. 2). Among C. melo rootstocks, reactions of 'Belimo' and 'Griffin' to the fungus resulted in higher levels of survival. Finally, the susceptible control Incas was completely wilted by the fungus with only a $2 \%$ survival.

The results of $D$. bryoniae resistance tests are reported in Figure 3. Among the genotypes tested, Cucurbita rootstocks ('RS 841', 'P 360', 'ES 99-13', 'Elsi') showed a high degree of resistance to $D$. bryoniae both on leaves and stems. Among C. melo rootstocks, 'Belimo' displayed a moderate severity of fungal attack, whereas 'Energia' was completely susceptible as the control Incas. Combining the results of inoculations both with the race 1,2w of FOM and $D$. bryoniae, the genotypes 'RS 841 ', ' $\mathrm{P}$ 360', 'ES 99-13', and 'Elsi' have shown the highest levels of control of both pathogens. The Cucumis rootstocks showed moderate reactions to the fungi that were significantly different in respect to Cucurbita rootstocks; in some cases (e.g., 'Energia' in the inoculations with $D$. bryoniae), they reacted similarly to the susceptible control Incas.

Yield and fruit quality. In both experiments, yield and mean fruit mass of grafted melons were highly influenced by the rootstock, whereas no significant differences among genotypes were observed for fruit number (Table 2). In Expt. 1 (2003), the graft combination Incas/RS 841 yielded $36 \%$ more than ungrafted plants. The Cucurbita rootstock RS 841 produced also yields 74\% higher than $C$. melo rootstocks ('Belimo', 'Energia', 'Griffin', 'ES liscio'). Plants grafted onto Cucurbita rootstocks, especially on 'RS 841', produced fruit weight larger than control and plants grafted onto $C$. melo rootstocks. The largest fruit weight was obtained by the same combination Incas/'RS 841 ', with $2.74 \mathrm{~kg}$, whereas the ungrafted control weighed $2.21 \mathrm{~kg}$. A similar trend was also observed in the Expt. 2, in which the Cucurbita rootstock 'RS 841' yielded 16\% and $22 \%$ more than both the $C$. melo rootstocks ('Belimo', 'Energia', 'Griffin', 'ES liscio') and the control, respectively (Table 2 ). The highest yield recorded on the graft combination Incas/'RS 841' with respect to the $C$. melo rootstocks and the control, was attributable to an increasing in the mean fruit mass and not to the number of fruit. Finally, total yield was generally lower in 2003 than in 2004 cropping season (Table 2).

In terms of fruit quality, no significant differences among rootstocks were observed for TSS contents (average $11.5^{\circ}$ Brix and

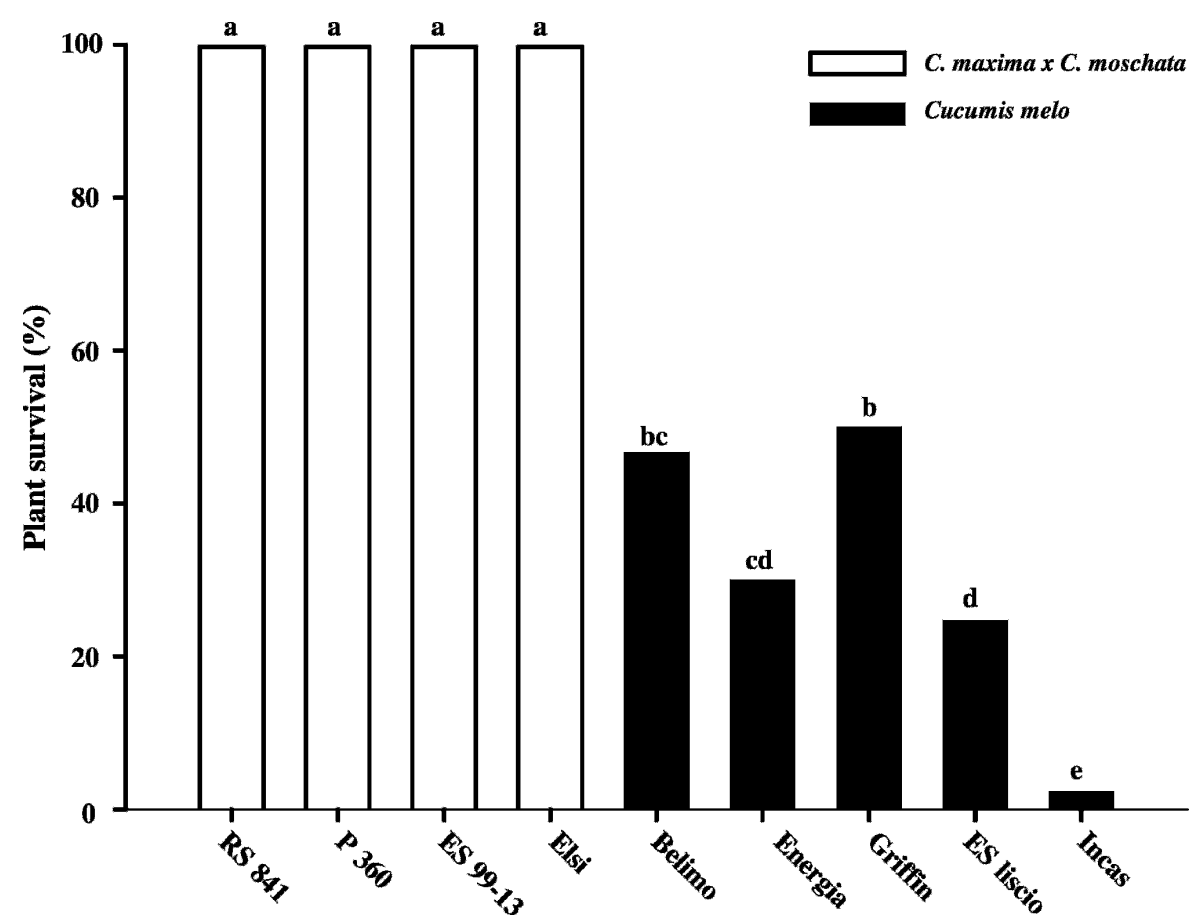

Fig. 2. Plant survival (\%) of eight commercial rootstocks and melon hybrid Incas recorded $40 \mathrm{~d}$ after inoculation with $F$. oxysporum $f$. sp. melonis, race $1,2 \mathrm{w}$. Different letters indicate significant differences according to Duncan's test $(P=0.05)$. 

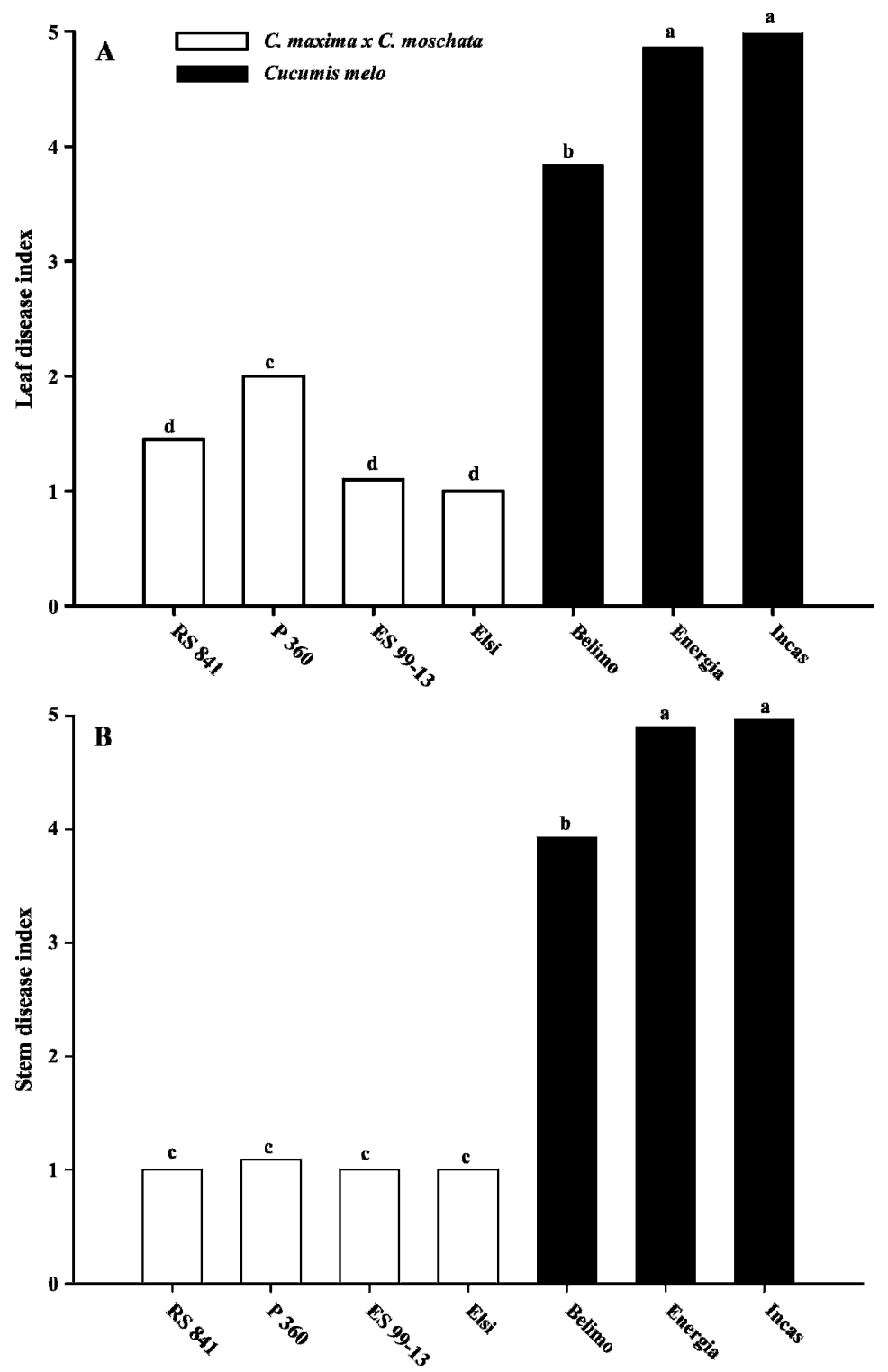

Fig. 3. Leaf (A) and stem (B) disease index of six commercial rootstocks and the melon hybrid Incas recorded $21 \mathrm{~d}$ after inoculation with $D$. bryoniae. (for leaves: $1=0 \%$ of leaf area affected, $5=75 \%$ to $100 \%$; for stems: $1=$ no damage, $5=$ seedling dead). Different letters indicate significant differences according to Duncan's test $(P=0.05)$.

Table 2. Total yield, mean fruit mass, and number of fruit of melon hybrid Incas when grafted on eight rootstocks and grown under greenhouse conditions in 2003 and 2004.

\begin{tabular}{|c|c|c|c|c|c|c|}
\hline \multirow[b]{2}{*}{ Grafting combination } & \multicolumn{2}{|c|}{ Yield $\left(\mathrm{kg} \cdot \mathrm{m}^{-2}\right)$} & \multicolumn{2}{|c|}{ Mean fruit mass $(\mathrm{kg})$} & \multicolumn{2}{|c|}{$\begin{array}{c}\text { Fruit number } \\
\left(\text { no. } / \mathrm{m}^{2}\right)\end{array}$} \\
\hline & 2003 & 2004 & 2003 & 2004 & 2003 & 2004 \\
\hline Incas (ungrafted) & $4.13{b c^{z}}^{2}$ & $7.05 \mathrm{~b}$ & $2.21 \mathrm{bc}$ & $1.88 \mathrm{ab}$ & $1.88 \mathrm{a}$ & $3.74 \mathrm{a}$ \\
\hline Incas/RS 841 & $5.60 \mathrm{a}$ & $8.14 \mathrm{a}$ & $2.74 \mathrm{a}$ & $2.08 \mathrm{a}$ & $2.05 \mathrm{a}$ & $3.92 \mathrm{a}$ \\
\hline Incas/P 360 & $3.71 \mathrm{bc}$ & $7.35 \mathrm{ab}$ & $2.57 \mathrm{ab}$ & $2.13 \mathrm{a}$ & $1.47 \mathrm{a}$ & $3.47 \mathrm{a}$ \\
\hline Incas/ES 99-13 & $4.55 \mathrm{ab}$ & $7.34 \mathrm{ab}$ & $2.43 \mathrm{abc}$ & $1.95 \mathrm{ab}$ & $1.88 \mathrm{a}$ & $3.78 \mathrm{a}$ \\
\hline Incas/Elsi & $4.11 \mathrm{bc}$ & $7.65 \mathrm{ab}$ & $2.45 \mathrm{abc}$ & $2.03 \mathrm{a}$ & $1.68 \mathrm{a}$ & $3.78 \mathrm{a}$ \\
\hline Incas/Belimo & $3.45 \mathrm{bc}$ & $6.41 \mathrm{~b}$ & $2.25 \mathrm{bc}$ & $1.74 \mathrm{~b}$ & $1.53 \mathrm{a}$ & $3.71 \mathrm{a}$ \\
\hline Incas/Energia & $2.93 \mathrm{c}$ & $6.90 \mathrm{~b}$ & $2.25 \mathrm{bc}$ & $1.88 \mathrm{ab}$ & $1.30 \mathrm{a}$ & $3.71 \mathrm{a}$ \\
\hline Incas/Griffin & $3.36 \mathrm{bc}$ & $7.02 \mathrm{~b}$ & $2.06 \mathrm{c}$ & $1.87 \mathrm{ab}$ & $1.62 \mathrm{a}$ & $3.74 \mathrm{a}$ \\
\hline Incas/ES liscio & $3.13 \mathrm{bc}$ & $6.42 \mathrm{~b}$ & $2.11 \mathrm{c}$ & $1.92 \mathrm{ab}$ & $1.56 \mathrm{a}$ & $3.36 \mathrm{a}$ \\
\hline Significance & $* *$ & * & * & * & NS & NS \\
\hline
\end{tabular}

Means within columns separated using Duncan's multiple range test $(P=0.05)$.

${ }_{\mathrm{Ns}, *, * *}$ Indicates nonsignificant or significant at $P \leq 0.05$ and 0.01 , respectively.

$10.9^{\circ}$ Brix in 2003 and 2004, respectively), fruit DM (average $11.3 \%$ and $11.1 \%$ in 2003 and 2004, respectively), titratable acidity (average $0.15 \%$ and $0.13 \%$ in 2003 and 2004, respectively), firmness (average 20.5 and $20.1 \mathrm{~N} / \mathrm{cm}$ in 2003 and 2004, respectively), and pulp color represented by $\mathrm{L}^{*}$ (average 65.3 and 62.9 in 2003 and 2004, respectively) and by the $\mathrm{a} * / \mathrm{b} *$ ratio (average -0.09 and -0.47 in 2003 and 2004, respectively) (Table 3 ).

\section{Discussion}

Considering the results of both inoculations with the race $1,2 \mathrm{w}$ of $F O M$ and with D. bryoniae, the Cucurbita genotypes 'RS 841', 'P 360', 'ES 99-13', and 'Elsi' have shown the highest levels of resistance to both pathogens and can be considered as rootstocks for melon cultivation under greenhouse conditions in infected soil by both these pathogens. Their use is of great interest mainly to overcome the diffusion of the race 1,2 of the pathogen FOM, already causing severe damage in South Italy (Belisario et al., 2000).

It was demonstrated that grafting per se affects directly plant yield (Nielsen and Kappel, 1996; Rivero et al., 2003). Its influence can be exerted by the interaction of some or all of the following processes such as an increase of water and nutrient uptake resulting from the rootstock's vigorous root system (Lee, 1994; Ruiz et al., 1997), an enhanced production of endogenous hormones (Zijlstra et al., 1994), and an enhancement of scion vigor (Leoni et al., 1990). The joint action of some or all of these processes could explain the highest yield of melon plants grafted, especially on Cucurbita-resistant rootstocks as observed in the current study on 'RS 841 '. The highest yield of melon, observed in this study from grafted plants, has been earlier reported also on watermelon (Yetisir and Sari, 2003), tomato (Fernandez-Garcia et al., 2004), eggplant (Khah, 2005), and melon (Ruiz and Romero, 1999). According to Ruiz and Romero (1999), the efficiency of grafting was significantly evident for fruit yield, in which fruit weight per plant was two times higher in the majority of grafted plants than in their controls. The highest yields recorded in the current experiment were not observed on all Cucurbita rootstocks suggesting that an accurate agronomic evaluation of the rootstock-scion combination is still necessary before using them on a commercial scale.

Exposure to higher-than-optimal temperatures reduces yield and impairs the quality of many crops, including vegetable crops (Erickson and Markhart, 2001; Firon et al., 2006). The highest air temperature recorded at the fruit set stage in 2003 with respect to the 2004 growing season was presumably responsible for the reduction in fruit set and productivity. Chronic heat stress, even at a mild degree, has been shown to disrupt the normal development of the gametes and thereby fruit set (Levy et al., 1978). Another interesting point observed in our study was that the rootstock 'RS 841' was found to be tolerant when grown under high-temperature conditions as observed in the 2003 growing season. There is general evidence that certain Cucurbita rootstocks may cause deterioration in fruit quality (Lee, 1994; Lee and Oda, 2003). In the present study, nutritional qualities such as fruit DM, titratable acidity, TSS content, and physical quality such as fruit firmness and Hunter color $\left(\mathrm{L}^{*}\right.$ and $\left.\mathrm{a}^{*} / \mathrm{b}^{*}\right)$ of grafted melons were similar to those of plants grown on their own roots (control). Therefore, the use of grafted melons under greenhouse 
Table 3. Fruit dry matter (DM), total soluble solids (TSS) contents, titratable acidity (TA), firmness, and hunter color values (L*, a*/b*) of melon hybrid Incas when grafted on eight rootstocks and grown under greenhouse conditions in 2003 and 2004.

\begin{tabular}{|c|c|c|c|c|c|c|c|c|c|c|c|c|}
\hline \multirow{2}{*}{$\begin{array}{l}\text { Grafting } \\
\text { combination }\end{array}$} & \multicolumn{2}{|c|}{ DM $(\%)$} & \multicolumn{2}{|c|}{ TSS ( ${ }^{\circ}$ Brix $)$} & \multicolumn{2}{|c|}{ TA $(\%)$} & \multicolumn{2}{|c|}{ Firmness $\left(\mathrm{N} / \mathrm{cm}^{2}\right)$} & \multicolumn{2}{|c|}{$\mathrm{L}^{*}$} & \multicolumn{2}{|c|}{$a * / b *$} \\
\hline & 2003 & 2004 & 2003 & 2004 & $\overline{2003}$ & 2004 & 2003 & 2004 & 2003 & 2004 & 2003 & 2004 \\
\hline Incas (ungrafted) & 11.2 & 10.7 & 11.5 & 11.0 & 0.15 & 0.12 & 20.8 & 19.7 & 65.5 & 63.2 & -0.05 & -0.43 \\
\hline Incas/RS 841 & 12.0 & 10.5 & 12.1 & 11.6 & 0.16 & 0.12 & 21.1 & 21.0 & 63.8 & 64.4 & -0.12 & -0.52 \\
\hline Incas/P 360 & 11.9 & 10.4 & 11.7 & 10.8 & 0.19 & 0.12 & 18.5 & 18.3 & 65.2 & 62.0 & -0.09 & -0.49 \\
\hline Incas/ES 99-13 & 11.7 & 10.6 & 11.6 & 10.9 & 0.15 & 0.11 & 17.4 & 20.8 & 65.4 & 63.2 & -0.12 & -0.50 \\
\hline Incas/Elsi & 10.5 & 11.3 & 10.8 & 11.1 & 0.16 & 0.13 & 21.6 & 18.4 & 65.3 & 62.6 & -0.06 & -0.47 \\
\hline Incas/Belimo & 12.1 & 11.0 & 11.8 & 10.6 & 0.15 & 0.12 & 20.8 & 18.6 & 64.6 & 63.4 & -0.06 & -0.43 \\
\hline Incas/Energia & 11.7 & 12.1 & 12.0 & 11.0 & 0.17 & 0.12 & 21.1 & 18.9 & 63.5 & 60.7 & -0.10 & -0.47 \\
\hline Incas/Griffin & 9.8 & 12.3 & 10.3 & 10.5 & 0.14 & 0.11 & 22.8 & 19.2 & 67.6 & 64.1 & -0.16 & -0.46 \\
\hline Incas/ES liscio & 10.9 & 10.9 & 11.8 & 10.4 & 0.16 & 0.10 & 21.8 & 18.6 & 66.9 & 62.2 & -0.12 & -0.43 \\
\hline Significance & NS & NS & NS & NS & NS & NS & NS & NS & NS & NS & NS & NS \\
\hline
\end{tabular}

Means within columns are separated by Duncan's multiple range test $(P=0.05)$.

${ }^{\text {Ns Nonsignificant. }}$

conditions would represent a potential strategy to increase total yield without having remarkable deterioration in the taste of melons.

In conclusion, the rootstock 'RS 841 ' was resistant to the race $1,2 \mathrm{w}$ of FOM and to $D$. bryoniae and was also the best genotype capable of significantly improving the productivity without a detrimental effect on fruit quality of the hybrid Incas used as a scion. 'RS 841' can be considered the most interesting rootstock among those tested for melon cultivation under greenhouse conditions.

\section{Literature Cited}

Armstrong, G.M. and G.K. Armstrong. 1978. Formae speciales and races of Fusarium oxysporum causing wilts of the Cucurbitaceae. Phytopathology 68:19-28.

Belisario, A., L. Luongo, L. Corazza, and T.R. Gordon. 2000. Indagini sulle popolazioni di Fusarium oxysporum f. sp. melonis in Italia. Colture Protette 3:87-89.

Bletsos, F.A. 2005. Use of grafting and calcium cyanamide as alternatives to methyl bromide soil fumigation and their effects on growth, yield, fruit quality and Fusarium wilt control in melon. J. Phytopathol. 153:155-161.

Cohen, R., Y. Burger, C. Horev, A. Porat, and M. Edelstein. 2005. Performance of Galia-type melons grafted onto Cucurbita rootstock in Monosporascus cannonballus-infested and noninfested soils. Ann. Appl. Biol. 146:381-387.

Cohen, R., C. Horev, Y. Burger, S. Shraiber, J. Hershenhorn, J. Katan, and M. Edelstein. 2002. Horticultural and pathological aspects of fusarium wilt management using grafted melons. HortScience 37:1069-1073.

Colla, G., Y. Rouphael, M. Cardarelli, D. Massa, A. Salerno, and E. Rea. 2006. Yield, fruit quality and mineral composition of grafted melon plants grown under saline conditions. J. Hort. Sci. Biotechnol. 81:146-152.

Davì, R., I. Ponti, and L. Rovesti. 1988. Dydimella bryoniae (Auersw.) Remh in coltivazioni di melone in Calabria. Informatore Fitopatologico 7-8:31-33.

Diffey, B. 2004. Climate change, ozone depletion and the impact of ultraviolet exposure of human skin. Phys. Med. Biol. 49:R1-R11.

Edelstein, M., R. Cohen, S. Shraiber, S. Pivonia, and D. Shteinberg. 1999. Integrated management of sudden wilt in melons caused by Monosporascus cannonballus using grafting and reduced rates of methyl bromide. Plant Dis. 83:1142-1145.

Erickson, A.N. and A.H. Markhart. 2001. Flower production, fruit set, and physiology of bell pepper during elevated temperature and vapor pressure deficit. J. Amer. Soc. Hort. Sci. 126:697-702.
Fernandez-Garcia, N., V. Martinez, A. Cerda, and M. Carvajal. 2004. Fruit quality of grafted tomato plants grown under saline conditions. J. Hort. Sci. Biotechnol. 79:995-1001.

Firon, N., R. Shaked, M.M. Peet, D.M. Phar, E. Zamski, K. Rosenfeld, L. Althan, and E. Pressman. 2006. Pollen grains of heat tolerant tomato cultivars retain higher carbohydrate concentration under heat stress conditions. Sci. Hort. 109:212-217.

Frantz, J.D. and M.M. Jahn. 2004. Five independent loci each control monogenic resistance to gummy stem blight in melon (Cucumis melo L.). Theor. Appl. Genet. 108:1033-1038.

ISTAT. 2005. www.istat.it/agricoltura/datiagri/ coltivazioni/ital2005.htmRome, Italy.

Katan, J., A. Greenberger, H. Alon, and A. Grinstain. 1976. Solar heating by polyethylene mulching for control of diseases caused by soilborne pathogens. Phytopathology 66:683-688.

Keinath, A.P., M.W. Farnham, and T.A. Zitter. 1995. Morphological, pathological, and genetic differentiation of Didymella bryoniae and Phoma spp. isolated from cucurbits. Phytopathology 85:364-369.

Khah, E.M. 2005. Effect of grafting on growth, performance and yield of aubergine (Solanum melongena L.) in the field and greenhouse. J. Food Agr. Environ. 3:92-94.

Lee, J.M. 1994. Cultivation of grafted vegetables. I. Current status, grafting methods, and benefits. HortScience 29:235-239.

Lee, J.M. and M. Oda. 2003. Grafting of herbaceous vegetable and ornamental crops. Hort. Rev. (Amer. Soc. Hort. Sci) 28:61-124.

Leoni, S., R. Grudina, M. Cadinu, B. Madeddu, and M.G. Carletti. 1990. The influence of four rootstocks on some melon hybrids and a cultivar in greenhouse. Acta Hort. 287:127-134.

Levy, A., H.D. Rabinowitch, and N. Kedar. 1978. Morphological and physiological characters affecting flower drop and fruit set of tomato at high temperatures. Euphytica 27:211-218.

Lhotsky, B., A. Lebeda, and J. Zvara. 1991. Resistance of wild Cucumis species to gummy stem blight (Didymella bryoniae). Acta Phytopathol. Entomol. Hung. 26:303-306.

McCreight, J.D., H. Nerson, and R. Grumet. 1993. Melon (Cucumis melo L.), p. 267-283. In: G. Kallo and B.O. Bergh (eds.). Genetic improvement of vegetable crops. Pergamon Press Ltd., Oxford.

Montzaka, S.A., J.H. Butler, R.C. Myers, T.M. Thompson, T.H. Swanson, A.D. Clarke, L.T Lock, and J. Elkins. 1996. Decline in the tropospheric abundance of halogen from halocarbons: Implications for stratospheric ozone depletion. Science 272:1318-1322.

Nielsen, G. and F. Kappel. 1996. 'Bing' sweet cherry leaf nutrition is affected by rootstock. HortScience 31:1169-1172.
Oda, M. 1995. New grafting methods for fruitbearing vegetables in Japan. Jpn. Agr. Res. Q. 29:187-198.

Perchepied, L., C. Dogimont, and M. Pitrat. 2005. Strain-specific and recessive QTLs involved in the control of partial resistance to Fusarium oxysporum $\mathrm{f}$. sp. melonis race 1,2 in a recombinant inbred line population of melon. Theor. Appl. Genet. 111:65-74.

Perchepied, L. and M. Pitrat. 2004. Polygenic inheritance of partial resistance to Fusarium oxysporum f. sp. melonis race 1,2 in melon. Phytopathology 94:1331-1336.

Ristaino, J.B. and W. Thomas. 1997. Agriculture, methyl bromide, and the ozone hole: Can we fill the gaps? Plant Dis. 81:964-977.

Rivero, R.M., J.M. Ruiz, and L. Romero. 2003. Role of grafting in horticultural plants under stress conditions. J. Food Agr. Environ. 1:70-74.

Ruiz, J.M., A. Belakbir, A. Lopez-Cantarero, and L. Romero. 1997. Leaf-macronutrient content and yield in grafted melon plants: A model to evaluate the influence of rootstock genotype. Sci. Hort. 71:227-234.

Ruiz, J.M. and L. Romero. 1999. Nitrogen efficiency and metabolism in grafted melon plants. Sci. Hort. 81:113-123.

Tjamos, E.C. and N. Makrinakis. 1990. Control of fungal wilt diseases of melon by application of soil Solarization Agadir, Morocco, Proc. 8th Conference Mediterranean Phytopathology Union, p. 423.

Trionfetti Nisini, P., A. Buzi, E. Granati, G. Chilosi, P. Crinò, and P. Magro. 2000. Screening for resistance to Didymella bryoniae in rootstocks of melon. OEPP/EPPO Bulletin 30:1-3.

Trionfetti Nisini, P., G. Colla, E. Granati, O. Temperini, P. Crinò, and F. Saccardo. 2002. Rootstock resistance to fusarium wilt and effect on fruit yield and quality of two muskmelon cultivars. Sci. Hort. 93:281-288.

Trionfetti Nisini, P., E. Granati, A. Belisario, L. Luongo, O. Temperini, and P. Crinò. 1999. Resistenza alla razza 1,2 di Fusarium oxysporum f.sp. melonis in portinnesti di melone. L'Informatore Agrario 44:45-47.

Wheeler, W.B. and N.S. Kawar. 1997. The solubility of methyl bromide in pure water, $35 \%$ sodium chloride and seawater. March Chem. 15:154-162.

Yetisir, H. and N. Sari. 2003. Effect of different rootstock on plant growth, yield and quality of watermelon. Austral. J. Expt. Agr. 43:1269-1274.

Zhang, Y., M. Kyle, C. Anagnostou, and T.A. Zitter. 1997. Screening melon (Cucumis melo) for resistance to gummy stem blight in the greenhouse and field. HortScience 32:117-121.

Zijlstra, S., S.P.C. Groot, and J. Jansen. 1994. Genotypic variation of rootstocks for growth and production in cucumber; possibilities for improving the root system by plant breeding. Sci. Hort. 56:185-196. 